Philip Nuss, Kevin H. Gardner, and Stefan Bringezu

\title{
Environmental Implications and Costs of Municipal Solid Waste- Derived Ethylene
}

Originally published as:

Nuss, P., K. H. Gardner, and S. Bringezu (2013):

Environmental Implications and Costs of Municipal Solid Waste-Derived Ethylene In: Journal of Industrial Ecology 17(6): 912-925

http://onlinelibrary.wiley.com/doi/10.1111/jiec.12066/abstract 
Philip Nuss ${ }^{a,}$, , Kevin H. Gardner ${ }^{b}$, and Stefan Bringezu ${ }^{c}$

\section{Environmental Implications and Costs of Municipal Solid Waste- Derived Ethylene}

a Yale School of Forestry \& Environmental Studies, New Haven, USA

b Environmental Research Group, University of New Hampshire, USA

c Wuppertal Institute for Climate, Environment and Energy, Research Group 3:

Material Flows and Resource Management, Wuppertal, Germany

* Corresponding author: Philip Nuss, Yale University, 195 Prospect St,

New Haven, CT 06511, USA

E-mail: philip@nuss.me

Phone: +12034320343

Fax: +412034325556 

This is the accepted version of the following article: Nuss, P., K.H. Gardner, and S. Bringezu. 2013. Environmental Implications and Costs of Municipal Solid Waste-Derived Ethylene. Journal of Industrial Ecology 17(6): 912-925, which has been published in final form at http://onlinelibrary.wiley.com/doi/10.1111/jiec.12066/abstract 
[Running Head: RESEARCH AND ANALYSIS]

[Running Foot: Nuss et al., Carbon Recycling: Fischer-Tropsch Synthesis]

\title{
Environmental Implications and Costs of Municipal Solid Waste-Derived Ethylene
}

\author{
Philip Nuss, Kevin H Gardner, Stefan Bringezu
}

Address correspondence to:

Philip Nuss

Yale Center for Industrial Ecology,

School of Forestry \& Environmental Studies

195 Prospect Street, USA

Email:philip@nuss.me

Keywords: carbon recycling, Fischer-Tropsch synthesis (FTS), life cycle assessment (LCA), industrial ecology, process-based cost analysis, waste-to-chemicals

Supporting information is available on the JIE Web site

\section{: II}


Summary:

Carbon recycling, in which organic waste is recycled into chemical feedstock for material production, may provide benefits in resource efficiency and a more cyclical economy - but may also create "trade-offs" in increased impacts elsewhere. We investigate the system-wide environmental burdens and cost associated with carbon recycling routes capable of converting municipal solid waste (MSW) via gasification and Fischer-Tropsch synthesis into ethylene. Results are compared to businessas-usual (BAU) cases in which ethylene is derived from fossil resources and waste is either landfilled with methane and energy recovery (BAU\#1) or incinerated (BAU\#2) with energy-recovery. Monte-Carlo and sensitivity analysis is used to assess uncertainties of the results. Results indicate that carbon recycling may lead to a reduction in cumulative energy demand (CED), total material requirement (TMR), and acidification when compared to BAU\#1. Global warming potential (GWP) is found to be similar or slightly lower than BAU\#1 and BAU\#2. In comparison to BAU\#2, carbon recycling results in higher CED, TMR, acidification and smog potential, mainly as a result of larger (fossil-based) energy offsets from energy-recovery. However, if a renewable power mix (envisioned for the future) is assumed to be offset, BAU\#2 impacts may be similar or higher than carbon recycling routes. Production cost per kilogram MSW-derived ethylene range between US\$1.85 to 2.06 (Jan 2011 US\$). This compares to US\$1.17 per kilogram for fossil-based ethylene. Waste-derived ethylene breaks even with its fossil-based counterpart at a tipping fee of roughly $\$ 42$ per metric ton of waste feedstock.

$<$ heading level $1>$ Introduction $<$ heading level $2>$ Challenges

The use of fossil-fuels is common in energy generation and in the production of chemical feedstocks such as olefins and their subsequent polymers. Shifting the resource base for chemical and energy production from fossil feedstocks to renewable raw materials is seen by many as one of the key strategies towards sustainable development. Current research and policy initiatives focus mainly on the utilization of lignocellulose biomass, originating from agriculture and forestry, as second 
generation feed-stocks for bioenergy production (i.e. fuels, heat and electricity) (Bringezu and Schütz 2008; Bringezu et al. 2007; Earley and McKeown 2009).

However, given a certain productivity per area, the current massive growth in global biofuels demand may, in the long term, only be met through an expansion of global arable land at the expense of natural ecosystems and in direct competition with the food-sector (Bringezu et al. 2009). Although many studies have shown the potential of biofuels production to reduce both greenhouse gas emissions and non-renewable energy consumption (Menichetti and Otto 2009; Zah and colleagues 2010), these production routes are still linear processes which depend on significant amounts of agricultural or forestry production area, and a growing demand may contribute to increased land use change and related tradeoffs (Bringezu et al. 2009).

$<$ heading level $2>$ Future vision

In the future, carbonaceous feedstocks and all other natural resources will need to be used much more efficiently and their use-phase within the technosphere prolonged. Cascading use, i.e. when biomass is used for material products (e.g. chemicals and subsequent polymers, pulp \& paper, construction materials) first and the energy content is recovered at the endof-life, may provide a greater environmental benefit than primary use as fuel (Bringezu et al. 2009; Dornburg 2004; Arnold et al. 2009; Weiss et al. 2007).

Going hand in hand with biomass cascading, the recycling of carbon flows from organic waste (i.e. biodegradable municipal solid waste (BMSW) and refuse-derived fuel (RDF), construction and demolition derived biomass, plastics wastes, and industrial organic wastes) could help to further reduce pressures on global terrestrial ecosystems. Currently, vast amounts of organic waste are discarded to landfills and incinerators in industrialized countries (EPA (U.S. Environmental Protection Agency) 2009a, 2009b; Eurostat 2009). Rapid economic growth and rise in community living standards in many of the low- or middle-income countries are likely to accelerate global waste generation and disposal rates (UN-HABITAT 2010). Disposal happens despite the fact that organic waste, being rich in carbon, could serve increasingly as feedstock for thermochemical (i.e. 
gasification and pyrolysis) and biochemical (i.e. fermentation and anaerobic digestion) technologies capable of recovering the carbon for further use as chemical feedstock ('carbon recycling').

Instead of releasing carbon stored in the organic waste into the atmosphere, by applying conventional waste management (WM) practices such as incineration, carbon recycling aims at capturing the carbon for use as material feedstock (Bringezu 2011, 2009). Technologies such as gasification and anaerobic digestion allow the generation of a syngas (CO and $\mathrm{H}_{2}$ ) or biogas $\left(\mathrm{CH}_{4}\right)$ from organic waste that can serve as feed not only for energy recovery but also for catalytic conversion towards important base chemicals such as naphtha and olefins. For example, the Fischer-Tropsch synthesis (FTS) (Spath and Dayton 2003) represents a widely applied route to provide base hydrocarbon mixtures from syngas which could then serve as an intermediate towards lower olefins (i.e. ethylene and propylene) (de Klerk et al 2005; Redman 2005; Steynberg et al 2004; Dancuar et al. 2003). Similarly, methanol-to-olefins (MTO) synthesis allows the production of olefins from syngas. Ethylene, for instance, represents a chemical intermediate from which a variety of different products can be obtained, in particular polymers such as polyethylene, polypropylene, polyethylene terephthalate, polyvinylchloride and polystyrene (Morschbacker 2009). Generating subsequent synthetic materials would allow the carbon to stay longer in the use-phase, therefore adding to the stock of durable goods in the technosphere. Polymers generated could be recycled at the end of product-life to provide feedstock for either energy generation or for the production of syngas for chemicals synthesis, therefore closing the loop ${ }^{1}$ (Nuss and colleagues 2012).

However, while a number of studies looked at the potentials of utilizing the organic waste fraction for both thermochemical and biochemical conversion (see (Nuss and colleagues 2012) for a literature summary), and some recent studies investigated environmental burdens associated with energy and fuels production from organic waste feedstock (Bez and colleagues 2001; Chester and Martin 2009; Kalogo and colleagues 2007; Khoo 2009; Münster and Lund 2009; Nuss and colleagues 2013; Stichnothe and Azapagic 2009), knowledge of the system-wide environmental impacts and economic costs associated with the provision of chemical feedstock and subsequent polymers (not just bio-fuels and energy) is still limited. 
$<$ heading level $2>$ Research question

Against this background, the central research question addressed in this paper is: What are the life-cycle wide environmental burdens associated with the production of ethylene from MSW via thermochemical routes and how do these compare to conventional fossil-based production routes as well as to current WM practices (i.e. landfilling and incineration)? While several routes are potentially capable of recovering carbon from organic waste for ethylene provision, this paper focuses specifically on the combination of gasification/FTS as an example of carbon recycling for which sufficient inventory data is available. In addition to environmental burdens, the study includes a cost analysis of some of the carbon recycling routes investigated. Ethylene was chosen as it currently represents one of the most versatile intermediates and highly optimized production routes (rigorous reference for comparison) towards industrial polymer production. Landfilling and incineration are chosen as comparative (business-as-usual) systems since the majority of waste in the United States (U.S.) is currently treated via these routes.

$<$ heading level $1>$ Methods

$<$ heading level 2> Life cycle assessment (LCA)

The main research method used is LCA (ISO (International Standard Organization) 2006a, 2006b) to evaluate the system-wide environmental impacts of carbon recycling and comparative systems. The waste-to-ethylene (foreground) system includes: 1.) Physical sorting of the mixed waste ${ }^{2}$ feedstock (MSW classification) and diversion of the refuse-derived biodegradable fraction $\left(\mathrm{BMSW}^{3}\right)$ to the gasification/FTS plant, 2.) Gasification and syngas cleaning, 3.) Catalytic conversion (FTS) followed by syncrude upgrading, and 4.) Steam cracking to obtain the final ethylene product ('cradle-to-factory gate'). Life cycle inventory (LCI) data comes from publically available sources including scientific publications and technical reports, as well as LCI databases (Ecoinvent 2010; NREL (National Renewable Energy Laboratory) 2008) and is given in detail in the supporting information available on the journal's Web site. Conversion systems are assumed to be located in the U.S. using regionspecific inventory data with regards to waste composition, technological parameters and background data to the extent 
possible. Technologies investigated are existing processes for which data is available on pilot or demonstration scale (e.g. waste gasification and FTS) as well as currently operated processes (e.g. municipal solid waste (MSW) classification and naphtha steam cracking). SimaPro 7.3 LCA software was used to develop the LCA model and carry out the life cycle impact assessment (LCIA). A combination of commonly used LCIA methods is used to assess global warming potential (GWP) and cumulative energy demand (CED) (Goedkoop et al. 2008), total material requirement (TMR) (MIPS ${ }^{4}$ (Lettenmeier et al. 2009; Ritthoff et al. 2002), water use (Goedkoop et al. 2009), and acidification and $\operatorname{smog}^{5}$ (Bare and colleagues 2002).

Carbon balance: Carbon accounting in LCA modeling of waste management systems is not always consistent (Christensen and colleagues 2009). Some models do not quantify biogenic carbon dioxide $\left(\mathrm{CO}_{2}\right)$ emissions, assuming carbon neutrality of waste biomass and neglecting potential carbon stock changes (Johnson 2009) within the technosphere, while others quantify but do not report biogenic $\mathrm{CO}_{2}$ emissions in GWP. Differences also exist in dealing with carbon temporarily sequestered in landfills and products which depends on the time horizon interested in when assessing GWP (Brandão and colleagues 2013; Christensen and colleagues 2009).

In our model, impacts to GWP consist of: (1) Emissions of fossil-based carbon as well as methane $\left(\mathrm{CH}_{4}\right)$ (from landfills), (2) Biogenic $\mathrm{CO}_{2}$ losses resulting from the treatment of BMSW, either by carbon recycling or conventional treatment (landfilling or incineration), and (3) Carbon storage ${ }^{6}$ for waste-carbon sequestered either in the final chemical product (ethylene) or in landfills. Quantifying biogenic $\mathrm{CO}_{2}$ accounts for the fact that by using BMSW for energy and/or chemicals recovery, carbon stocks within the technosphere are in fact depleted (e.g. woody biomass wastes may have been part of the technosphere stock of carbon for several years). Carbon storage accounts for the fact that, similar to carbon sinks in landfills, carbon recycling schemes producing platform chemicals (ethylene) for further use in durable goods would prolong the retention time of carbon within the technosphere ${ }^{7}$.

However, we recognize that there are multiple approaches to biogenic carbon accounting. Hence, in order to allow for transparency in impacts to GWP, we report the detailed shares of fossil vs. biogenic carbon emissions and carbon sequestration with our results 
$<$ heading level 3> Comparison of carbon recycling with business-as-usual (BAU) scenario

We compare carbon recycling, which diverts organic waste feedstock and generates 1 kilogram $(\mathrm{kg})$ of ethylene (functional unit), to a 'business as usual' (BAU) case in which conventional waste treatment is applied and ethylene is derived from fossil resources (Figure 1). ${ }^{8}$ In this comparison, the environmental burdens associated with the use of MSW for producing $1 \mathrm{~kg}$ of ethylene (system [B]) is compared to the environmental load associated with conventional treatment (i.e. $100 \%$ landfilling (BAU\#1) or 100\% incineration (BAU\#2)) of an equivalent amount of waste and the production of $1 \mathrm{~kg}$ fossilbased ethylene (system $[\mathrm{A}])$.

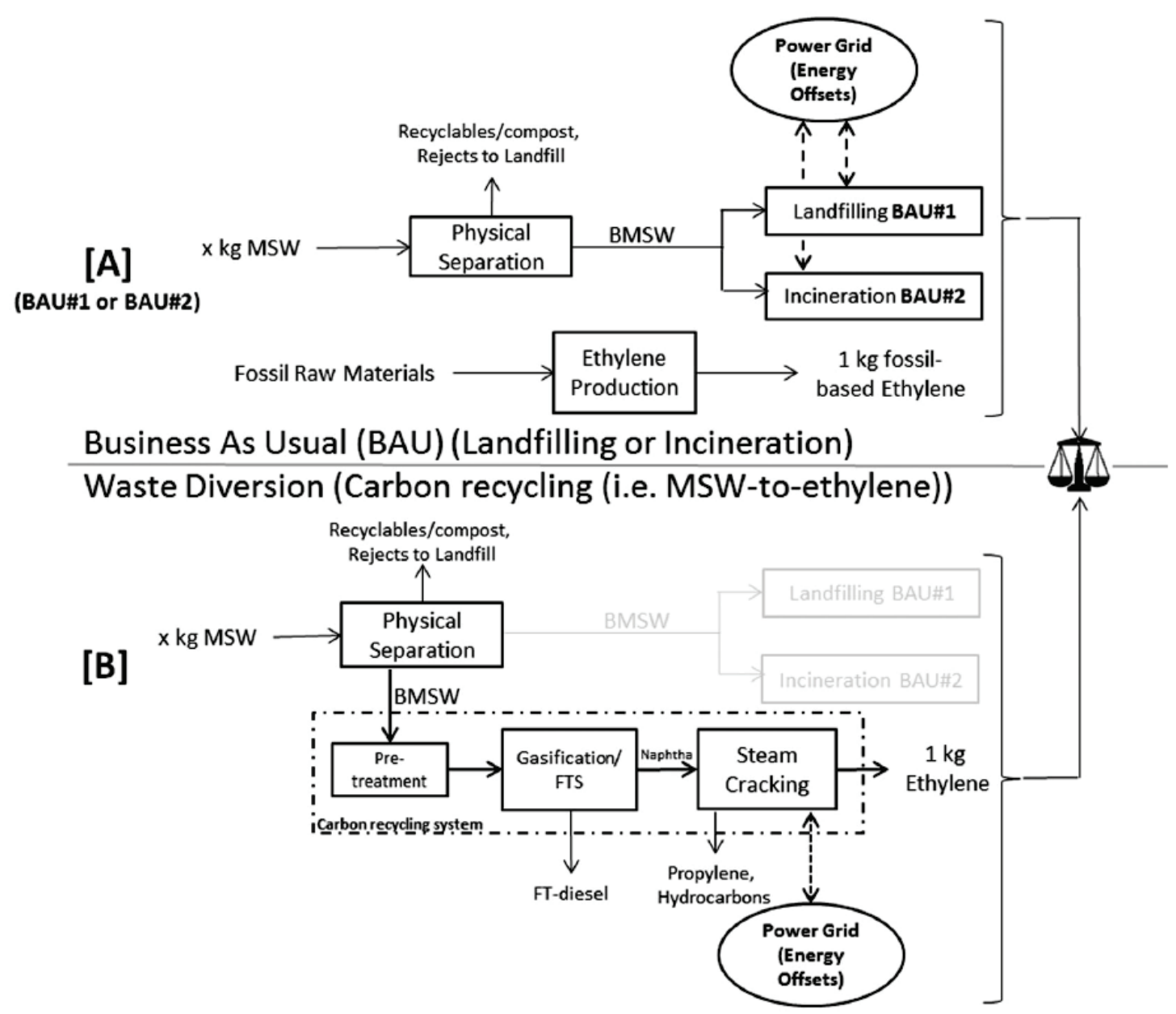

Figure 1. Production of ethylene as waste management option. The functional unit for comparison is $\mathbf{1} \mathrm{kg}$ of ethylene at the factory gate. BAU: Business-As-Usual. MSW: Municipal Solid Waste. BMSW: Biodegradable Municipal Solid Waste (refuse-derived from front-end classification). FT: Fischer-Tropsch. 
Landfills and incinerators generate electricity offsetting conventional power from the U.S. average power grid (Ecoinvent 2010) (system expansion). For carbon recycling systems, we use a combined allocation/system expansion approach in which environmental burdens from multi-output processes (MSW classification, FTS, and steam cracking) are allocated based on physical relationships, i.e. energy content for Fischer-Tropsch (FT)-diesel and FT-naphtha from FTS, and mass for outputs from MSW classification (BMSW, recyclables/compostables, and scraps) and steam cracking (ethylene, propylene and other hydrocarbons). Similar to WM systems in the BAU scenarios, excess electricity co-produced from FTS is treated via system expansion, whereby electricity replaced is assumed to come from the U.S. average power grid.

$<$ heading level 3 $>$ Uncertainty assessment and sensitivity analysis

We use Monte Carlo (MC) simulation to estimate combined LCI parameter uncertainties of our LCA model with details given in the supporting information on the Web (section 1.2). Furthermore, we test the sensitivity of assumptions made on the LCA results by varying assumptions regarding (1) Allocation (physical vs. economic), (2) Future low carbon energy mix (using energy shares from the International Energy Agency (IEA) BlueMap Scenario (IEA (International Energy Agency) 2010)) and energy substitution (substitution of non-baseload ${ }^{9}$ power in the U.S. (EPA (U.S. Environmental Protection Agency) 2011)), (3) Increased conversion efficiency (from BMSW to FTS), and (4) Energy inputs to the steam cracker (see the supporting information on the Web, section 3.7).

$<$ heading level $2>$ Cost analysis

Process based cost analysis (Kirchain and Field 2000) is used to estimate the costs related to carbon recycling systems under investigation. Costs are given per functional unit of $1 \mathrm{~kg}$ of ethylene. The LCI provides the quantities of material and energy flows, and consumption-related costs are obtained by multiplying these quantities with the respective market prices. Included are also typical costs for residue disposal (e.g. waste water, ash, slag, etc.) in the U.S. 
The cost perspective chosen is the cost for the product manufacturer. All costs are corrected for inflation and recalculated for January 2011 (base year) (USDOL (United States Department of Labor) 2011).

One time capital expenses (i.e. equipment and engineering \& contingency) are allocated over a depreciation period using the capital recovery factor $(\mathrm{CRF})$ :

$$
C R F=\frac{\left[r(1+r)^{m}\right]}{\left[(1+r)^{m}-1\right]}
$$

In this equation, $\mathrm{m}$ is the number of years over which the cost is allocated and $\mathrm{r}$ equals the discount rate (Kirchain and Field 2000). For this study we use: period under consideration $(\mathrm{m})=20$ years; and discount rate $(\mathrm{r})=8 \%$. This results in a CRF of $10.19 \%{ }^{10}$. The equipment was assumed to run for 8395 hours a year or 365 days a year and 23 hours a day. The time deducted takes into account possible unplanned downtime.

If not included in the capital cost figures, project contingencies were added to the equipment costs to cover project uncertainty and the cost of any additional equipment that could result from a more detailed design. The total capital investment (TCI) of a conversion plant is then equal to the sum of the equipment and contingency cost. Cost contingencies applied to economic analysis of gasification/FTS facilities range from 10 - 30\% (Hamelinck 2004; Niessen et al 1996; Van Bibber et al. 2007; van Vliet et al 2009). For this study, a 15\% project contingency is applied to the entire plant (in addition to installation factors given in the literature) and a process contingency of $25 \%$ applied to the FTS unit to reflect larger uncertainty relative to other sub-processes (Van Bibber and colleagues 2007).

Operating cost figures include material and energy cost, waste treatment cost, operating labor, as well as maintenance cost and other overhead expenses. The prices of FT diesel, propylene, other hydrocarbons and electricity are based on a constant average oil price of 79-104 US\$/bbl for the time frame 2010 to 2011 (see the supporting information on the Web, section 4). 
$<$ heading level $1>$ Inventory data

A brief description of LCI data sources and assumptions is given below. More details are provided in the supporting information on the Web.

$<$ heading level 2> Carbon recycling systems

We investigate carbon recycling systems using inventory data for three different gasification/FTS systems, namely Battelle, MTCI, and Choren (see the supporting information on the Web, table S2). While the Battelle and MTCI gasifiers underwent pilot runs using RDF (Niessen et al. 1996; Paisley et al. 1989; Jungbluth et al. 2007), inventory data for the Choren system is based on wood chips use only (Jungbluth et al. 2007; RENEW 2006). However, personal communications with Choren indicated that the Carbo-V gasifier was able to successfully convert dry stabilate as well as waste tires into a clean synthesis gas during test-runs in the past (Bilas 2010). This study assumes that MSW classification and subsequent drying will provide a feedstock of sufficient purity to be fed to the Carbo-V gasifier. The Choren datasets are used to cross-check results of the other two conversion systems investigated. In general, carbon recycling via FTS is mostly suited for dry waste feedstock, while wet waste is more appropriate for biochemical conversion routes (Kamm et al. 2006). The combination of front-end classification (Broder and colleagues 1993), generating a 'waste fluff', and subsequent drying using waste heat from the gasification process, is assumed to provide a waste feed of sufficient quality for gasification ${ }^{11}$. Subsequent FTS (syngas to FTliquids) is based on inventory data from (Van Bibber and colleagues 2007; Jungbluth and colleagues 2007b; Marano and Ciferno 2001), while the naphtha steam cracking step (FT-naphtha to ethylene) is based on (CPM (Centrum för Produktrelaterad Miljöanalys) 2010; Dancuar and colleagues 2003; UBA (Umweltbundesamt) 2010).

$<$ heading level 2> Business-as-usual (BAU) cases

Carbon recycling systems are compared to a BAU case in which $1 \mathrm{~kg}$ ethylene stems from fossil fuels (NREL (National Renewable Energy Laboratory) 2008) (i.e. natural gas in the U.S.) and BMSW is either landfilled or incinerated (both with 
energy recovery) (Figure 1). Greenhouse gas (GHG) emissions associated with U.S. average landfills receiving BMSW come from the U.S. Environmental Protection Agency (EPA) Waste Reduction Model (WARM) (EPA (U.S. Environmental Protection Agency) 2006) (0.572 kg carbon dioxide equivalent $\left[\mathrm{CO}_{2}\right.$-eq] per kg BMSW). ${ }^{12}$ Since the WARM model only provides impacts to GWP, all other impacts are derived using European reference Life Cycle Database (ELCD) data in which $22 \%$ landfill gas is recovered for flaring and 28\% used for energy generation $(0.10$ kilowatt-hours per kilogram [kWh $/ \mathrm{kg}]$ BMSW) ${ }^{13}$ offsetting conventional grid power (European Commission 2011).

Inventory data for waste incineration is taken from the ELCD database (European Commission 2011). Most of the waste-to-energy (WtE) plants in the U.S. recover electricity (EPA (U.S. Environmental Protection Agency) 2006). Given a power generation efficiency for RDF facilities of $16.3 \%{ }^{14}$ (EPA (U.S. Environmental Protection Agency) 2006) and an energy content of 11.588 megajoules per kilogram (MJ/kg) BMSW, 0.53 kilowatt-hours per kilogram BMSW are delivered to the grid offsetting conventional power. ${ }^{15}$ TMR data for both incineration and landfilling were obtained from (Schmidt 2003).

$<$ heading level 2> Energy systems

We use data from (Ecoinvent 2010) for current U.S. average power $\left(0.76 \mathrm{~kg} \mathrm{CO} \mathrm{C}_{2}\right.$ eq/ $\mathrm{kWh}$ ) and from (IEA (International Energy Agency) 2010; Koornneef and colleagues 2008; Ecoinvent 2010) for a future low-carbon power mix (IEA BLUE Map Scenario, $0.206 \mathrm{~kg} \mathrm{CO}-e q / \mathrm{kWh}^{16}$ (see sensitivity analysis), to model energy in- and outputs (offsets) as part of the foreground system The marginal power mix (consisting of 100\% coal (NREL (National Renewable Energy Laboratory) 2008 ); $1.31 \mathrm{~kg}$ $\left.\mathrm{CO}_{2}-\mathrm{eq} / \mathrm{kWh}\right)^{17}$ comes from plants that are more likely to respond to incremental changes in electricity supply and demand (see the supporting information on the Web, section 2.7).

$<$ heading level $1>$ Results and discussion

A brief discussion of LCIA results is given below. More details are provided in the supporting information on the Web, sections 3 and 4. 
$<$ heading level 2> Environmental assessment

Table 1 summarizes the environmental impacts that are estimated to occur if BMSW were used as feedstock for $1 \mathrm{~kg}$ ethylene production. The BAU scenarios show the environmental burdens of generating an equivalent amount of ethylene from fossil raw-materials in the U.S. and take into account that BMSW would be either landfilled (BAU\#1) or incinerated (BAU\#2). Relative contributions of unit processes to MSW-to-ethylene pathways are shown in Figure 2. Table 2 shows the breakdown of GWP into fossil and biogenic carbon emissions as well as carbon sequestered.

Table 1 Environmental burdens associated with the production of $1 \mathrm{~kg}$ ethylene from municipal solid waste (MSW) and when compared to respective business-as-usual (BAU) scenarios.

\begin{tabular}{|c|c|c|c|c|c|c|c|}
\hline Impact category & Unit & MSW Route & SD & $2.5 \%$ & $97.5 \%$ & $\begin{array}{l}\text { BAU\#1, } \\
\text { Landfilling }^{3}\end{array}$ & $\begin{array}{l}\text { BAU\#2, } \\
\text { Incineration }^{3}\end{array}$ \\
\hline \multicolumn{8}{|l|}{ Battelle } \\
\hline GWP $(\text { total })^{1}$ & $\mathrm{~kg} \mathrm{CO}_{2}$-eq & $1.258 \mathrm{E}+01$ & $2.59 \mathrm{E}+00$ & $8.55 \mathrm{E}+00$ & $1.87 \mathrm{E}+01$ & $1.256 \mathrm{E}+01$ & $1.382 \mathrm{E}+01$ \\
\hline CED & MJ-eq & $3.035 \mathrm{E}+01$ & $9.25 \mathrm{E}+00$ & $1.86 \mathrm{E}+01$ & $5.44 \mathrm{E}+01$ & $8.214 \mathrm{E}+01$ & $-3.142 \mathrm{E}+01$ \\
\hline TMR & $\mathrm{kg}$ & $3.696 \mathrm{E}+00$ & $5.52 \mathrm{E}-01$ & $2.76 \mathrm{E}+00$ & $5.00 \mathrm{E}+00$ & $1.441 \mathrm{E}+01$ & $5.924 \mathrm{E}-01$ \\
\hline Acidification & $\mathrm{H}+$ moles-eq & 7.499E-01 & $1.25 \mathrm{E}-01$ & $5.44 \mathrm{E}-01$ & $1.03 \mathrm{E}+00$ & $1.547 \mathrm{E}+00$ & $-4.438 \mathrm{E}-01$ \\
\hline Smog & g NOx-eq & $9.172 \mathrm{E}-03$ & $1.60 \mathrm{E}-03$ & $6.52 \mathrm{E}-03$ & $1.29 \mathrm{E}-02$ & $8.319 \mathrm{E}-03$ & $1.156 \mathrm{E}-03$ \\
\hline Water use & $\mathrm{m}^{3}$ & $1.069 \mathrm{E}-02$ & $1.98 \mathrm{E}-03$ & $7.29 \mathrm{E}-03$ & $1.50 \mathrm{E}-02$ & $1.665 \mathrm{E}-03$ & 4.203E-02 \\
\hline \multicolumn{8}{|l|}{ MTCI } \\
\hline GWP $(\text { total })^{1}$ & $\mathrm{~kg} \mathrm{CO}_{2}$-eq & $1.019 \mathrm{E}+01$ & $2.97 \mathrm{E}+00$ & $4.85 \mathrm{E}+00$ & $1.87 \mathrm{E}+01$ & $1.107 \mathrm{E}+01$ & $1.065 \mathrm{E}+01$ \\
\hline CED & MJ-eq & $2.745 \mathrm{E}+01$ & $8.04 \mathrm{E}+00$ & $1.70 \mathrm{E}+01$ & $4.57 \mathrm{E}+01$ & $8.129 \mathrm{E}+01$ & $-1.725 \mathrm{E}+01$ \\
\hline TMR & $\mathrm{kg}$ & $3.259 \mathrm{E}+00$ & $7.44 \mathrm{E}-01$ & $2.03 \mathrm{E}+00$ & $4.93 \mathrm{E}+00$ & $1.302 \mathrm{E}+01$ & $1.029 \mathrm{E}+00$ \\
\hline Acidification & $\mathrm{H}+$ moles-eq & $6.900 \mathrm{E}-01$ & $1.71 \mathrm{E}-01$ & 3.94E-01 & $1.05 \mathrm{E}+00$ & $1.542 \mathrm{E}+00$ & $-1.855 \mathrm{E}-01$ \\
\hline Smog & g NOx-eq & $8.746 \mathrm{E}-03$ & $2.52 \mathrm{E}-03$ & $4.28 \mathrm{E}-03$ & $1.41 \mathrm{E}-02$ & 7.619E-03 & $1.403 \mathrm{E}-03$ \\
\hline Water use & $\mathrm{m}^{3}$ & $1.029 \mathrm{E}-02$ & $3.40 \mathrm{E}-03$ & $4.28 \mathrm{E}-03$ & $1.75 \mathrm{E}-02$ & $1.464 \mathrm{E}-03$ & $3.649 \mathrm{E}-02$ \\
\hline \multicolumn{8}{|l|}{ Choren } \\
\hline GWP (total) ${ }^{1}$ & $\mathrm{~kg} \mathrm{CO}_{2}$-eq & $4.866 \mathrm{E}+00$ & $1.27 \mathrm{E}+00$ & $2.73 \mathrm{E}+00$ & $7.52 \mathrm{E}+00$ & $7.664 \mathrm{E}+00$ & $8.684 \mathrm{E}+00$ \\
\hline CED & MJ-eq & $2.831 \mathrm{E}+01$ & $8.42 \mathrm{E}+00$ & $1.90 \mathrm{E}+01$ & $4.57 \mathrm{E}+01$ & $7.895 \mathrm{E}+01$ & $2.187 \mathrm{E}+01$ \\
\hline $\mathrm{TMR}^{2}$ & $\mathrm{~kg}$ & - & - & - & - & $9.179 \mathrm{E}+00$ & $2.232 \mathrm{E}+00$ \\
\hline Acidification & $\mathrm{H}+$ moles-eq & $6.205 \mathrm{E}-01$ & $1.30 \mathrm{E}-01$ & 4.42E-01 & $9.28 \mathrm{E}-01$ & $1.528 \mathrm{E}+00$ & $5.274 \mathrm{E}-01$ \\
\hline Smog & g NOx-eq & 7.924E-03 & $2.72 \mathrm{E}-03$ & $4.59 \mathrm{E}-03$ & $1.49 \mathrm{E}-02$ & $5.685 \mathrm{E}-03$ & $2.084 \mathrm{E}-03$ \\
\hline Water use & $\mathrm{m}^{3}$ & $1.269 \mathrm{E}-02$ & $2.18 \mathrm{E}-03$ & $8.90 \mathrm{E}-03$ & $1.74 \mathrm{E}-02$ & $9.086 \mathrm{E}-04$ & $2.120 \mathrm{E}-02$ \\
\hline
\end{tabular}

${ }^{1}$ Global Warming Potential (GWP) includes all fossil and biogenic carbon emissions as well as carbon storage in ethylene and landfills. ${ }^{2}$ Total material requirement (TMR) has been excluded due to the aggregated nature of the Choren dataset. ${ }^{3}$ Includes environmental burdens of producing 
$1 \mathrm{~kg}$ of fossil-based ethylene. SD: Standard deviation. 2.5\%/97.5\% represents the $95 \%$ confidence interval according to Monte-Carlo (MC) analysis. A total of $1000 \mathrm{MC}$ runs were carried out for each parameter and system under investigation. One gram $(\mathrm{g})=10^{-3} \mathrm{kilograms}(\mathrm{kg}, \mathrm{SI}) \approx 0.035$ ounces (oz). One cubic meter $\left(\mathrm{m}^{3}, \mathrm{SI}\right)=10^{3}$ liters $(\mathrm{L}) \approx 264.2$ gallons (gal). CED = Cumulative Energy Demand. $\mathrm{H}+$ moles-eq $=$.

Table 2 Breakdown of Global Warming Potential (GWP) into fossil/methane and biogenic carbon emissions, as well as carbon sequestered per kg ethylene at the factory gate.

\begin{tabular}{|c|c|c|c|c|}
\hline & $\begin{array}{l}\text { Unit } \\
\text { [per kg ethylene] }\end{array}$ & MSW Route & BAU\#1, Landfilling & BAU\#2, Incineration \\
\hline \multicolumn{5}{|l|}{ Battelle } \\
\hline GWP (fossil) & $\mathrm{kg} \mathrm{CO}_{2}$-eq & 1.96 & $1.76^{1}$ & $-5.03^{1,2}$ \\
\hline GWP $\left(\mathrm{CH}_{4}\right.$ from landfills $)$ & $\mathrm{kg} \mathrm{CO}$-eq & 0.00 & 17.58 & 0.00 \\
\hline GWP (biogenic $\mathrm{CO}_{2}$ ) & $\mathrm{Kg} \mathrm{CO}_{2}$-eq & 13.77 & 5.59 & 18.85 \\
\hline GWP (total) excluding carbon storage & $\mathrm{kg} \mathrm{CO}$-eq & 15.73 & 24.93 & 13.82 \\
\hline Net carbon storage & $\mathrm{kg} \mathrm{CO}_{2}$-eq & $-3.15^{3}$ & $-12.37^{4}$ & 0.00 \\
\hline GWP (total), including carbon storage ${ }^{5}$ & $\mathrm{~kg} \mathrm{CO}_{2}$-eq & 12.58 & 12.56 & 13.82 \\
\hline \multicolumn{5}{|l|}{ MTCI } \\
\hline GWP (fossil) & $\mathrm{kg} \mathrm{CO}_{2}$-eq & 1.79 & $1.69^{1}$ & $-4.20^{1,2}$ \\
\hline GWP $\left(\mathrm{CH}_{4}\right.$ from landfills $)$ & $\mathrm{kg} \mathrm{CO}_{2}$-eq & 0.00 & 15.26 & 0.00 \\
\hline GWP (biogenic $\mathrm{CO}_{2}$ ) & $\mathrm{kg} \mathrm{CO}_{2}$-eq & 11.56 & 4.85 & 14.85 \\
\hline GWP (total) excluding carbon storage & $\mathrm{kg} \mathrm{CO}_{2}$-eq & 13.35 & 21.80 & 10.65 \\
\hline Net carbon storage & $\mathrm{kg} \mathrm{CO}_{2}$-eq & $-3.15^{3}$ & $-10.73^{4}$ & 0.00 \\
\hline GWP (total), including carbon storage ${ }^{5}$ & $\mathrm{~kg} \mathrm{CO}_{2}$-eq & 10.19 & 11.07 & 10.65 \\
\hline \multicolumn{5}{|l|}{ Choren } \\
\hline GWP (fossil) & $\mathrm{kg} \mathrm{CO}_{2}$-eq & 2.02 & $1.55^{1}$ & $-2.30^{1,2}$ \\
\hline GWP ( $\mathrm{CH}_{4}$ from landfills) & $\mathrm{kg} \mathrm{CO}_{2}$-eq & 0.00 & 9.96 & 0.00 \\
\hline GWP (biogenic $\mathrm{CO}_{2}$ ) & $\mathrm{kg} \mathrm{CO}_{2}$-eq & 6.00 & 3.17 & 10.99 \\
\hline GWP (total) excluding carbon storage & $\mathrm{kg} \mathrm{CO}_{2}$-eq & 8.02 & 14.67 & 8.68 \\
\hline Net carbon storage & $\mathrm{kg} \mathrm{CO}_{2}$-eq & $-3.15^{3}$ & $-7.00^{4}$ & 0.00 \\
\hline GWP (total), including carbon storage ${ }^{5}$ & $\mathrm{~kg} \mathrm{CO}_{2}$-eq & 4.87 & 7.66 & 8.68 \\
\hline
\end{tabular}

${ }^{1}$ Includes environmental burdens of producing $1 \mathrm{~kg}$ of fossil-based ethylene. ${ }^{2}$ Negative burden due to energy offsets being larger than fossil-based greenhouse

gas emissions. ${ }^{3}$ Based on carbon content of $1 \mathrm{~kg}$ ethylene at the factory gate. ${ }^{4}$ Carbon sequestered in landfills (Based on WARM model numbers. See the supporting information for more details). ${ }^{5}$ Reported in this study (Table 1). GWP(total) $=\mathbf{G W P}($ fossil $)+\mathbf{G W P}\left(\mathrm{CH}_{4}\right)+\mathbf{G W P}\left(\mathrm{biogenic} \mathrm{CO} \mathbf{O}_{2}\right)+\mathrm{Net} \mathrm{Carbon}$ Storage. MSW = Municipal Solid Waste. BAU = Business-as-usual. 


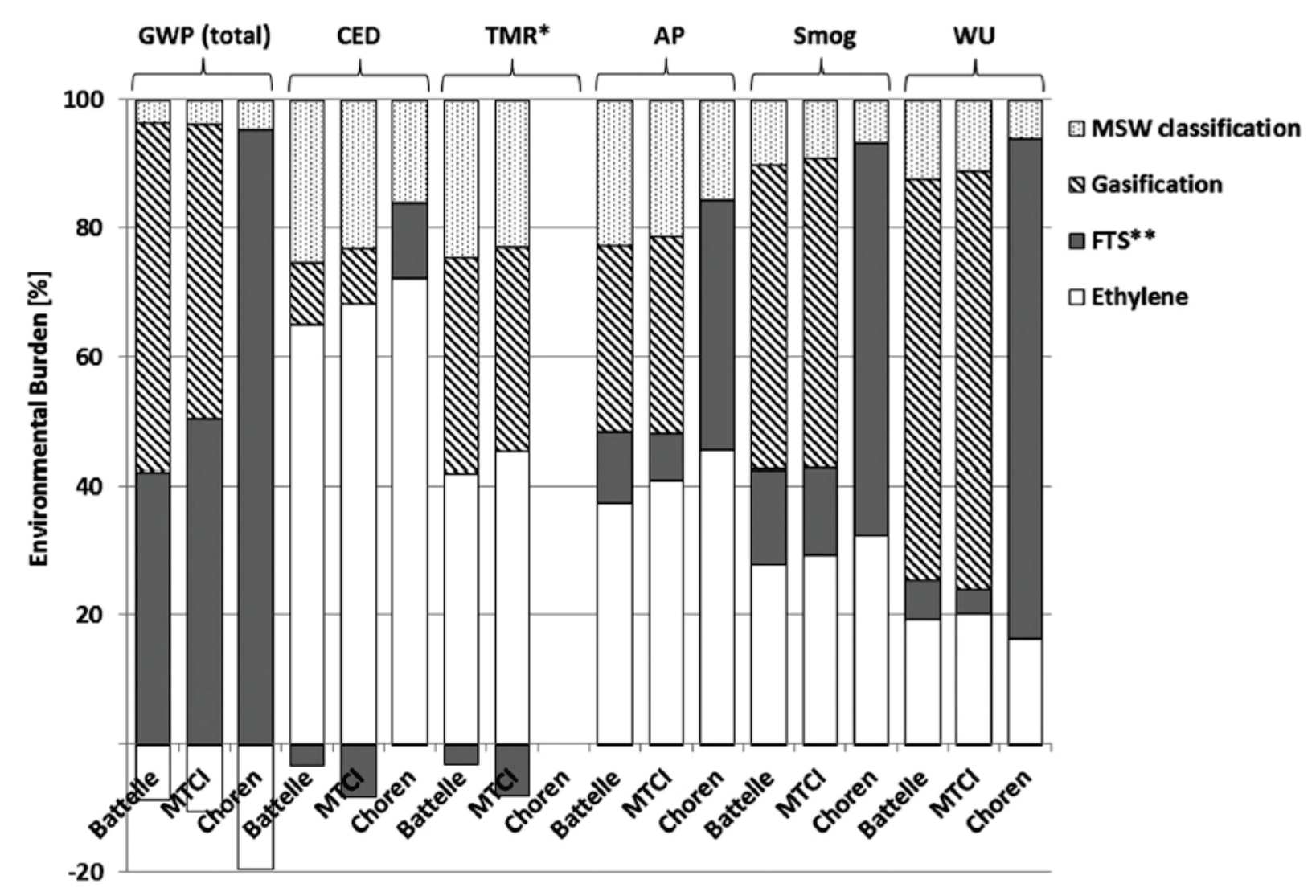

Figure 2. Relative contributions of unit processes to system-wide environmental burdens of municipal solid waste (MSW)-to-ethylene technologies. Negative burdens indicate energy offsets from excess electricity co-produced at the Fischer-Tropsch Synthesis (FTS) unit (system expansion) and/or carbon storage. *TMR for the Choren system has been excluded due to the aggregated nature of the dataset. **FTS for the Choren plant includes gasification and FT-naphtha production (aggregated dataset). GWP: Global Warming Potential; CED: Cumulative Energy Demand; TMR: Total Material Requirement; AP: Acidification potential; WU: Water use.

Conversion efficiencies: Applying allocation based on physical relationships, $10.7 \mathrm{~kg}$ BMSW (Choren), $16.4 \mathrm{~kg}$ BMSW (MTCI), and $18.9 \mathrm{~kg}$ BMSW (Battelle) are required for the generation of $1 \mathrm{~kg}$ of ethylene at the factory gate. The lower feedstock requirements of the Choren plant is due to a higher lower-heating value (LHV) conversion efficiency ${ }^{18}$ of $53 \%$ (from BMSW to FT-liquids) when compared to only $27 \%$ and $31 \%$ for the Battelle and MTCI systems, respectively (see the supporting information on the Web, table S6). We investigate the impact of varying conversion efficiencies on the overall environmental burdens as part of the sensitivity analysis. 
Interpretation of results: Results of the assessment show that when compared to BAU\#1 MSW-ethylene routes lead to lower environmental burdens with regards to CED, TMR and acidification, but to higher impacts to smog and water use. GWP associated with MSW-to-ethylene production is roughly similar to landfilling. Impacts of BAU\#1 to all categories are positive, even if the avoided burdens of LFG energy recovery are taken into account. As a result, BAU\#1 impacts are higher for the Battelle and MTCI landfilling scenarios, diverting larger amounts of BMSW, than for the Choren landfilling scenario (Table 1).

On the other hand, larger energy offsets associated with BMSW incineration drastically reduces environmental impacts to all categories in BAU\#2, except GWP and water use, resulting in lower impacts when compared to the respective MSW-toethylene routes (Table 1). In BAU\#2, negative impacts to CED and acidification are due to the avoided impacts of fossil energy offsets being larger than the cumulative environmental burdens of fossil-based ethylene production and waste treatment via incineration. Water use was found to be highest for BAU\#2 scenarios.

GWP is largely governed by biogenic $\mathrm{CO}_{2}$ and $\mathrm{CH}_{4}$ emissions from BMSW feedstock utilization (Table 2). While both MSW-to-ethylene routes and landfills sequester a portion of the waste carbon, incinerators release all carbon back to the atmosphere during combustion. Hence, notwithstanding rather efficient energy recovery, GWP (total) is within the range of other systems investigated. However, impacts to GWP are influenced by assumptions made with regards to carbon storage in the ethylene product (carbon recycling) and landfills (BAU\#1). Excluding sequestration credits from the analysis, i.e. not converting carbon stored into $\mathrm{CO}_{2}$ equivalents and subtracting them from the sum of fossil and biogenic carbon emissions, leads to an increase in total GWP of $3.15 \mathrm{~kg} \mathrm{CO}_{2}$ for MSW-to-ethylene routes (based on a carbon content of $0.86 \mathrm{~kg} / \mathrm{kg}$ ethylene), and $7.0-12.4 \mathrm{~kg} \mathrm{CO}$-eq for BAU\#1 (based on landfills net carbon storage given in (EPA (U.S. Environmental Protection Agency) 2006)) (all numbers per kg ethylene). As a result, BAU\#1 has the highest GWP (Table 2) This simple analysis shows how assumptions with regards to carbon accounting can change the outcome of the analysis with regards to GWP. 
For MSW-to-ethylene systems, impacts to GWP, CED, and TMR are, to a large extent, due to energy inputs (heat) to the steam cracker (Figure 2), converting FT-naphtha into light olefins. During the FTS step, electricity is co-produced, most of which is used internally. However, both the MTCI and Battelle conversion systems generate a small amount of excess electricity (0.26 and $0.17 \mathrm{kWh} / \mathrm{kg}$ FT-liquids) offsetting conventional electricity from the U.S. national grid (negative burdens in Figure 2). Negative burdens to GWP are also due to carbon sequestered in the ethylene product. Impacts from MSW classification to all categories are due to electricity requirements (33kWh/metric ton) to the front-end sorting system. ${ }^{19}$

Impacts from gasification are largest for GWP, TMR, acidification, smog, and water use. For GWP this is due to onsite emissions of biogenic $\mathrm{CO}_{2}$, while impacts to TMR are mainly a result of inputs of gasifier bed materials, chemicals and water (syngas cleanup). Acidification impacts are largely a result of on-site emissions of sulfur dioxide $\left(\mathrm{SO}_{2}\right)$ and nitrogen oxides $\left(\mathrm{NO}_{\mathrm{x}}\right)$ during gasification, FTS, and steam cracking (off-gases). Similarly, smog potential is mainly due to $\mathrm{NO}_{\mathrm{x}}$ and volatile organic compounds (VOCs) emitted on-site. While typical off-gas emission profiles from gasification are based on actual organic waste treatment (Khoo 2009) and those of FTS on biomass gasification (Marano and Ciferno 2001), we use emissions profiles from conventional fossil-based naphtha steam crackers using crude-oil because other data are unavailable ${ }^{20}$ (Dancuar and colleagues 2003; CPM (Centrum för Produktrelaterad Miljöanalys) 2010; UBA (Umweltbundesamt) 2010). While FT-naphtha is generally free of sulfur and nitrogen compounds (de Klerk 2007, 2008), fossil-based naphtha may carry higher amounts of these pollutants. The lack of actual emissions data from waste-derived naphtha steam cracking is reflected in uncertainties, in particular with regard to smog (Table 1).

Water use is dominated by the gasification process. This is due to direct inputs of feedwater for steam production, cooling, and use in wet scrubbers (syngas cleaning). In addition, water is used in many of the chemicals inputs to gas cleaning such as sodium hydroxide $(\mathrm{NaOH})$ and sulfuric acid $\left(\mathrm{H}_{2} \mathrm{SO}_{4}\right)($ Ecoinvent 2010$)$.

Although not assessed in a quantitative manner, MSW-to-ethylene related impacts to land occupation and indirect land use change are likely to be minimal when compared to biomass-based routes. Carbon recycling systems can utilize and divert organic waste feedstock that would otherwise go to landfills and incinerators. Carbon stored in chemical end-products and 
plastics would delay atmospheric GHG emissions. Their reuse by the very same systems (gasifiers may use any type of organic waste including the plastic fraction) reduces the area of land required for carbon uptake to produce virgin biomass.

However, current carbon recycling efficiencies from BMSW to ethylene are only about $19 \%$ for the Battelle, $24 \%$ for the MTCI, and 33\% for the Choren system ${ }^{21}$. With improvements in conversion efficiencies (see sensitivity analysis) this percentage may be increased and more carbon kept within the technosphere.

$<$ heading level 2> Marginal power mix and future energy scenario

Assuming marginal ${ }^{22}$ energy offsets leads to minimal changes in environmental burdens associated with MSW-toethylene routes (see the supporting information on the Web, section 3.7.2). This is due to only small amounts of power coproduced by the FTS unit. For BAU scenarios, replacing more carbon-intensive energy at the margins, leads to lower environmental impacts.

Under a future energy scenario, using power shares from the IEA Blue Map scenario, MSW-to-ethylene routes may result in lower impacts with regards to GWP, TMR, acidification, and water use (and roughly similar impacts with regards to CED for the Choren route) when compared to BAU\#2 (see the supporting information on the Web, section 3.7.2). This is due to a less carbon and energy intensive power mix being offset and indicates that while under current conditions carbon recycling may only be environmentally superior to conventional landfilling (and incineration with regards to GWP and water use), in the long-term (i.e. 2050 (BLUE Map scenario)) the shift towards alternative sources of energy could lead to carbon recycling having similar or slightly higher impacts than WtE production via conventional incineration ${ }^{23}$.

$<$ heading level 2> Sensitivity analysis

Results of our analysis were found to be sensitive to varying conversion efficiencies and energy inputs to the steam cracker, as well as to the choice of allocation for by-products generated (see the supporting information on the Web, section 3.7). Optimizing current system configurations to increase conversion efficiencies (we assume up to $50 \%$ from BMSW to FT- 
liquids based on the fact that 50-60\% efficiencies are expected by biomass-based systems (see the supporting information on the Web, table S6) and reduce heat inputs to the steam cracker could lead to a significant reduction in environmental burdens. Considering economic instead of physical allocation may exclude environmental burdens associated with MSW classification (due to the low value of BMSW) therefore resulting in a further reduction in environmental burdens, in particular with regards to GWP and CED.

$<$ heading level $2>$ Cost analysis

When all parameters are set at their 'base-value', the production costs of $1 \mathrm{~kg}$ ethylene at the factory gate are US\$2.06 for the Battelle and US\$ 1.85 for the MTCI system, respectively (Jan 2011 US\$). This compares to currently US\$1.17 per kg fossil-based ethylene in the U.S. (CMAI (Chemical Market Associates, Inc.) 2011). The lower cost for ethylene produced via the MTCI route is due to a slightly higher conversion efficiency which is, however, offset to some extent by less revenue obtained from BMSW tipping fees.

Parameters largely affecting the final ethylene costs are shown in Table 3. We vary each of these parameters between the ranges given in the table to determine the sensitivity of the cost figures. Figure 3 shows results of the sensitivity analysis for the Battelle system as example. 
Table 3 Main parameters used for the cost analysis and the ranges for the sensitivity analysis. Product prices indicate revenue streams. Biodegradable municipal solid waste (BMSW) represents a revenue stream because a tipping fee would be collected by waste managers to landfill or incinerate the waste feedstock.

\begin{tabular}{|c|c|c|c|}
\hline Parameter & Unit & Value & Range \\
\hline Capital cost & US\$/kg ethylene & 3.11 (varies per concept) & $70-130 \%$ \\
\hline BMSW tipping fee & US\$/metric ton & 30 & $15-45$ \\
\hline FT-diesel & $\mathrm{US} \$ / \mathrm{kg}$ & 0.99 & $0.6-1.4$ \\
\hline Propylene & $\mathrm{US} \$ / \mathrm{kg}$ & 1.57 & $0.94-2.19$ \\
\hline Other hydrocarbons & US\$ $/ \mathrm{kg}$ & 0.96 & $0.5-1.4$ \\
\hline Interest rate $(\mathrm{r})$ & $\%$ & 8 & $4-12$ \\
\hline Depreciation period (m) & Years & 20 & $10-30$ \\
\hline Load factor & hours/year & 8395 & $6716-8760$ \\
\hline
\end{tabular}

Note: FT: Fischer-Tropsch

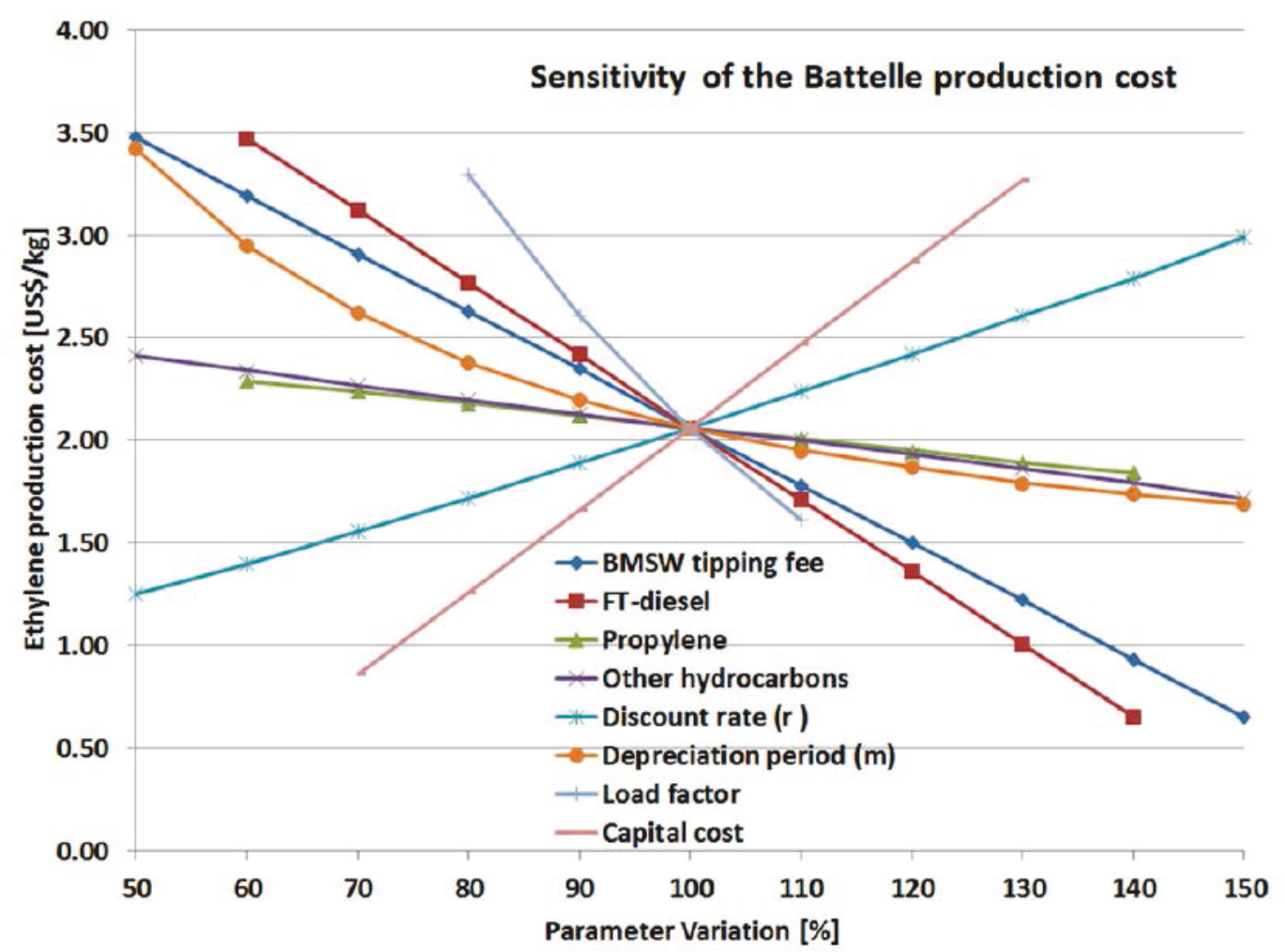

Figure 3. Sensitivity of the production cost of the Battelle carbon recycling system to the parameter variation. Please note that $100 \%$ on the axis corresponds to the base value of the cost model (zero variation). BMSW: Biodegradable Municipal Solid Waste. FT: Fischer-Tropsch. 
Possible price fluctuations in revenues associated with by-products such as FT-diesel and other hydrocarbons as well as variations in cost model parameters such as capital cost and load factors were found to have a significant effect on the ethylene production cost (Figure 3). In this regard, further research in the effects of price volatility and anticipated future oil prices on the production cost of carbon recycling would be of interest. Due to the preliminary nature of equipment cost this factor represents a major uncertainty.

Furthermore, the feedstock price for the carbon recycling technologies was varied from $\$-70$ to $\$+50$ per metric ton (Figure 4). Here, the negative prices indicate a tipping fee which is likely to vary depending on the region (e.g. highly populated areas are likely to charge a higher tipping fee than rural areas). On average, conventional biomass costs $\$ 48.5$ per dry metric ton (Valkenburg and colleagues 2008) and hence we choose a maximum price of \$50/metric ton.

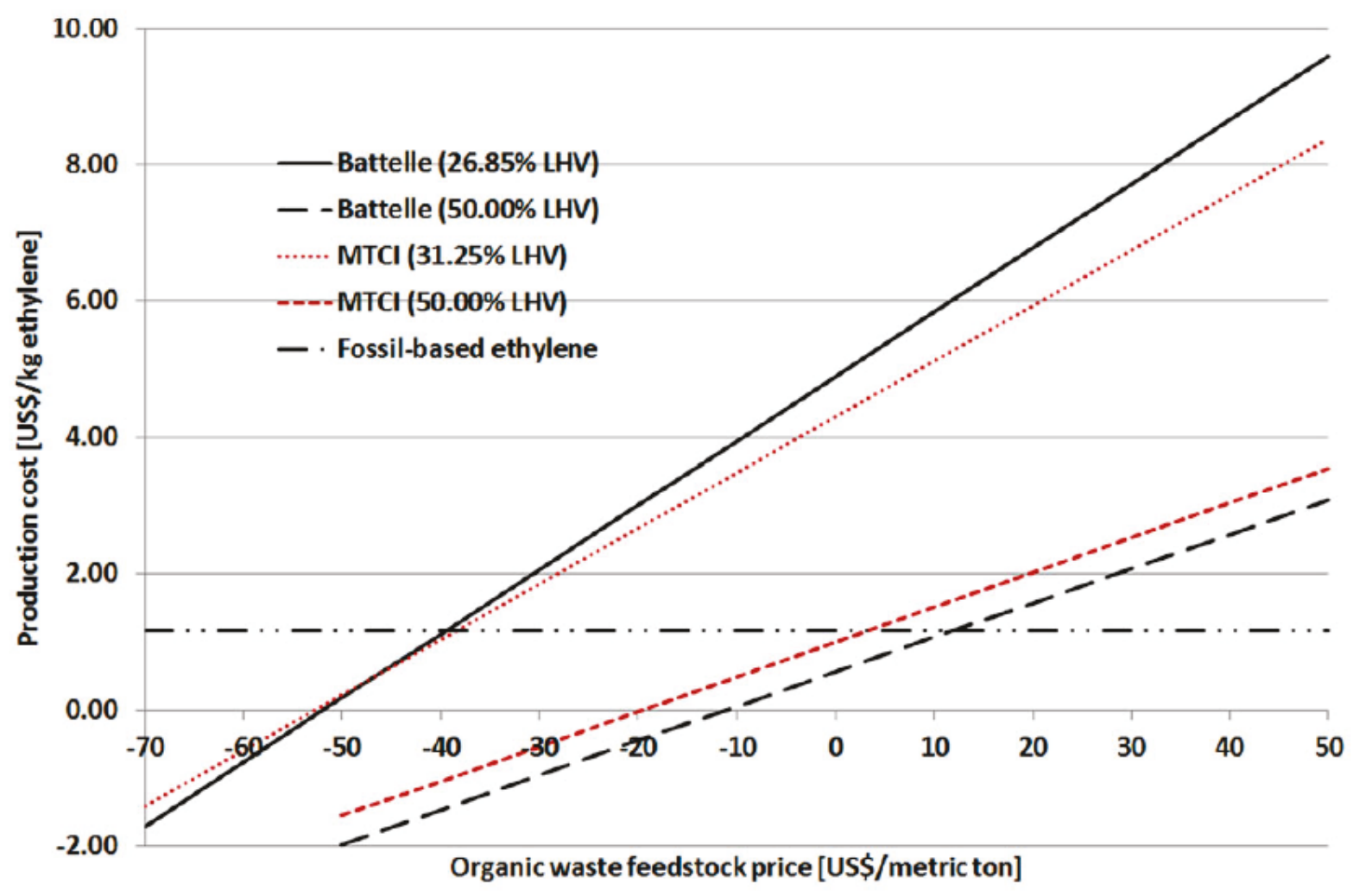

Figure 4. Ethylene production cost versus waste feedstock price for the Battelle and MTCI system. LHV: Lower Heating Value (conversion efficiency). 
Figure 4 shows that at current LHV conversion efficiencies (from BMSW to FT-liquids) a tipping fee of roughly $\$ 42$ per metric ton, both waste-to-ethylene systems may become economically competitive to fossil-based ethylene production. However, if carbon recycling systems were able to achieve higher conversion efficiencies of 50\%, as reported in the literature for biomass-based FTS systems, ethylene production might be economically viable even if no tipping fee is charged. In the figure, flatter slopes at higher conversion efficiencies indicate that less waste feedstock is required per kg of ethylene and hence production cost are less impacted by changes in BMSW cost. At a feedstock price of $\$ 50$ per metric ton, carbon recycling at higher conversion efficiencies may allow ethylene production at costs of $\$ 3.10$ to $\$ 3.55$.

$<$ heading level $1>$ Conclusion

Our study has shown that carbon recycling, in which organic waste is recycled into naphtha for chemical feedstock production, may have the potential to reduce environmental burdens with regards to GWP, CED, TMR, and acidification when compared to conventional landfilling and fossil-based ethylene production in the U.S. (BAU\#1). However, when compared to incineration with energy-recovery, as it is implemented in European countries, carbon recycling based on currently available technologies results in higher system-wide impacts with regards to CED, TMR, acidification, and smog potential - mainly as a result of large energy offsets associated with waste incineration. However, in the future energy offsets may not be as significant as power comes increasingly from renewable sources and hence carbon recycling routes may become increasingly competitive to conventional incineration systems.

While production costs seem not yet competitive to fossil-based ethylene provision, our cost comparison did not account for costs of BMSW treatment in a comparative BAU scenario. Under current conditions, waste-derived ethylene seems to breakeven with its fossil-based counterpart at a tipping fee of roughly $\$ 42$ per metric ton of waste feedstock (and at a tipping fee of $\$ 5$ to $\$ 10$ at higher conversion efficiencies of 50\% (from BMSW to FT-liquids)). 
The modeled carbon recycling routes are based on existing technologies available today (though not in an integrated fashion). Uncertainty ranges associated with our results, derived from a combination of existing data, semi-quantitative approaches and sensitivity analysis, are large and may differ from those obtained in more detailed engineering design studies. Absolute results of our study should therefore be used with caution and many uncertainties will remain until the actual operation of similar integrated systems. However, our study was able to indicate the sources of large uncertainties, and identify the subsystems of the life-cycles responsible for the highest environmental burdens and costs.

The LCA approach taken provides first insights into the system-wide environmental burdens associated with the investigated conversion systems. Nevertheless, to more fully understand the consequences and indirect implications of waste diversion on large scales a follow-up study might apply consequential LCA (Earles and Halog 2011; Ekvall 2000) to carbon recycling routes in the United States and other regions.

\section{Acknowledgments}

The authors would like to acknowledge the Graduate School and Natural Resources and Earth System Science PhD program at the University of New Hampshire for funding this research. We would also like to thank three anonymous reviewers for their valuable comments that helped to further improve the manuscript. 


\section{REFERENCES}

Arnold, K., J. Geibler, K. Bienge, C. Stachura, S. Borbonus, and K. Kristof. 2009. Kaskadennutzung von nachwachsenden Rohstoffen: Ein Konzept zur Verbesserung der Rohstoffeffizienz und Optimierung der Landnutzung [Cascading use of renewable resources: A concept to improve and optimize land use]. Wuppertal Papers. Wuppertal, Germany: Wuppertal Institut für Klima, Umwelt, Energie GmbH.

http://www.wupperinst.org/en/info/entwd/index.html?beitrag_id=1163\&bid=43\&searchart=publikationen_uebersicht. Accessed December 14, 2009.

Bare, J.C., G.A. Norris, D. Pennington, and T. McKone. 2002. Traci - The tool for the reduction and assessment of chemical and other environmental impacts. Journal of Industrial Ecology 6(3-4): 49-78. Accessed January 29, 2010.

Bez, J., G. Goldhan, and B. Buttker. 2001. Methanol aus Abfall - Ökobilanz bescheinigt gute Noten [Methanol from waste Life Cycle Assessment attests good performance]. Müll und Abfall(3): 158-162. Accessed December 17, 2009.

Bibber, L. Van, E. Shuster, J. Haslbeck, M. Rutkowski, S. Olson, and S. Kramer. 2007. Technical and Economic Assessment of Small-Scale Fischer-Tropsch Liquids Facilities. U.S. Department of Energy/National Energy Technology Laboratory, February 27. http://www.purdue.edu/discoverypark/energy/pdfs/cctr/DOE-NETL-F-T-2007.pdf. Accessed October 25, 2010.

Bilas, I. 2010. Personal Communication. August 19.

Brandão, M., A. Levasseur, M.U.F. Kirschbaum, B.P. Weidema, A.L. Cowie, S.V. Jørgensen, M.Z. Hauschild, D.W. Pennington, and K. Chomkhamsri. 2013. Key issues and options in accounting for carbon sequestration and temporary storage in life cycle assessment and carbon footprinting. The International Journal of Life Cycle Assessment 18(1): 230-240. Accessed May 21, 2013.

Bringezu, S. 2009. Chapter 4: Visions of a sustainable resource use. In Sustainable Resource Management: Global Trends, Visions and Policies, ed by. Stefan Bringezu and Raimund Bleischwitz, 155-215. Sheffield, UK: Greenleaf Publishing, September 30.

Bringezu, S. 2011. Key elements for economy-wide sustainable resource management. Annales de Mines(61). Special Edition: "Une croissance verte? Responssabilite \& Environnement: 78-87.

Bringezu, S., S. Ramesohl, K. Arnold, M. Fischedick, J. Geibler, C. Liedtke, and H. Schütz. 2007. Towards a sustainable biomass strategy - A discussion paper of the Wuppertal Institute. Wuppertal Papers, Wuppertal Institute for Climate, Environment and Energy 163. http://www.wupperinst.org/uploads/tx_wibeitrag/WP163.pdf. Accessed April 16, 2009.

Bringezu, S. and H. Schütz. 2008. Auswirkungen eines verstärkten Anbaus nachwachsender Rohstoffe im globalen Maßstab [Implications of increased cultivation of renewable resources globally]. Technikfolgenabschätzung - Theorie und Praxis 17(2): 12-23. Accessed April 14, 2009.

Bringezu, S., H. Schütz, K. Arnold, F. Merten, S. Kabasci, P. Borelbach, C. Michels, G.A. Reinhardt, and N. Rettenmaier. 2009a. Global implications of biomass and biofuel use in Germany - Recent trends and future scenarios for domestic and foreign agricultural land use and resulting GHG emissions. Journal of Cleaner Production 17(Supplement 1): S57S68. Accessed December 11, 2009.

Bringezu, S., H. Schütz, M. O’Brien, L. Kauppi, R.W. Howarth, and J. McNeely. 2009b. Towards sustainable production and use of resources: Assessing Biofuels. UNEP Resource Panel. United Nations Environment Programme (UNEP). http://www.unep.fr/scp/rpanel/pdf/Assessing_Biofuels_Full Report.pdf. Accessed December 5, 2009.

Broder, J., M. Eley, and J. Barrier. 1993. Municipal solid waste and waste cellulosics conversion to fuels and chemicals Volume II: Front-end classification systems. Muscle Shoals, Alabama: Tennessee Valley Authority, March.

Chester, M. and E. Martin. 2009. Cellulosic Ethanol from Municipal Solid Waste: A Case Study of the Economic, Energy, and Greenhouse Gas Impacts in California. Environmental Science \& Technology 43(14): 5183-5189.

Chiang, N. 2005. Quantifying the economic potential of a biomass to olefin technology. MasterThesis, Massachussets Institute of Technology (MIT). http://dspace.mit.edu/handle/1721.1/33628. Accessed October 19, 2009. 
Christensen, T.H., E. Gentil, A. Boldrin, A.W. Larsen, B.P. Weidema, and M. Hauschild. 2009. C balance, carbon dioxide emissions and global warming potentials in LCA-modelling of waste management systems. Waste Management \& Research 27(8): 707-715. Accessed May 21, 2013.

CMAI (Chemical Market Associates, Inc.). 2011. Momomers Market Report - Data Supplement. Issue No. 55. Houston, Texas: CMAI Global, March 31. www.cmaiglobal.com. Accessed July 29, 2011.

CPM (Centrum för Produktrelaterad Miljöanalys). 2010. CPM LCA Database. Goteborg, Sweden: Center for Environmental Assessment of Product and Material Systems (CPM), Chalmers University of Technology. http://www.cpm.chalmers.se/CPMDatabase/. Accessed November 22, 2010.

Dancuar, L., J. Mayer, M. Tallman, and J. Adams. 2003. Performance of the SASOL SPD naphtha as steam cracking feedstock. Preprints of American Chemical Society (a Division of Petroleum Chemistry) 48: 132-138.

Dornburg, V. 2004. Multi-functional biomass systems. Dissertation, Department of Science, Technology and Society, Utrecht University, The Netherlands. http://igitur-archive.library.uu.nl/dissertations/2004-1207-114735/index.htm. Accessed December 14, 2009.

Earley, J. and A. McKeown. 2009. Smart Choices for Biofuels. Washington D.C.: Worldwatch Institute and Sierra Club. http://www.worldwatch.org/smartchoicesforbiofuels. Accessed October 26, 2009.

Ecoinvent. 2010. Ecoinvent Life Cycle Inventory database v2.2. Swiss Centre for Life Cycle Inventories. http://www.ecoinvent.ch/. Accessed November 7, 2010.

EPA (U.S. Environmental Protection Agency). 2006. Solid Waste Management and Greenhouse Gases: Documentation for Greenhouse Gas Emission and Energy Factors Used in the Waste Reduction Model (WARM). 3rd Edition. U.S. Environmental Protection Agency. http://epa.gov/climatechange/wycd/waste/SWMGHGreport.html\#documentation. Accessed December 11, 2010.

EPA (U.S. Environmental Protection Agency). 2009a. Municipal Solid Waste Generation, Recycling and Disposal in the United States: Facts and Figures for 2008. U.S. Environmental Protection Agency. http://www.epa.gov/waste/nonhaz/municipal/pubs/msw2008rpt.pdf. Accessed December 20, 2009.

EPA (U.S. Environmental Protection Agency). 2009b. Municipal Solid Waste Generation, Recycling, and Disposal in the United States Detailed Tables and Figures for 2008. U.S. Environmental Protection Agency. http://www.epa.gov/waste/nonhaz/municipal/pubs/msw2008data.pdf. Accessed December 20, 2009.

EPA (U.S. Environmental Protection Agency). 2011. eGRID 2010 Version 1.1. http://www.epa.gov/cleanenergy/energyresources/egrid/index.html. Accessed June 1, 2011.

European Commission. 2011. ELCD core database version II. Joint research Centre - LCA Tools, Services and Data. http://lca.jrc.ec.europa.eu/lcainfohub/datasetArea.vm. Accessed May 31, 2011.

Eurostat. 2009. Environmental Data Centre on Waste. http://epp.eurostat.ec.europa.eu/portal/page/portal/waste/introduction. Accessed December 21, 2009.

Goedkoop, M., R. Heijungs, M. Huijbregts, A. De Schryver, J. Struijs, and R. Van Zelm. 2009. ReCiPe 2008, A life cycle impact assessment method which comprises harmonised category indicators at the midpoint and the endpoint level; First edition Report I: Characterisation. January 6. http://www.lcia-recipe.net. Accessed March 27, 2010.

Goedkoop, M., M. Oele, A. de Sch, and M. Vieira. 2008. SimaPro Database Manual - Methods library. Netherlands: PRé Consultants, May. http://www.pre.nl/download/manuals/DatabaseManualMethods.pdf. Accessed November 30, 2010.

Hamelinck, C.N. 2004. Outlook for advanced biofuels. PhD Thesis, Utrecht University, The Netherlands. http://igiturarchive.library.uu.nl/dissertations/2005-0209-113022/. Accessed August 22, 2009.

IEA (International Energy Agency). 2010. Energy Technology Perspectives 2010 - Scenarios \& Strategies to 2050. Executive Summary. Paris: International Energy Agency. http://www.iea.org/techno/etp/index.asp. Accessed July $20,2011$.

ISO (International Standard Organization). 2006a. Environmental Management - Life Cycle Assessment - Principles and Framework, ISO14040. Geneva, Switzerland: ISO.

ISO (International Standard Organization). 2006b. Environmental Management - Life Cycle Assessment - Requirements and Guidelines, ISO 14044. Geneva, Switzerland: ISO. 
Johnson, E. 2009. Goodbye to carbon neutral: Getting biomass footprints right. Environmental Impact Assessment Review 29(3): 165-168. Accessed March 27, 2011.

Jungbluth, N., M. Chudacoff, A. Dauriat, F. Dinkel, G. Doka, M.F. Emmenegger, E. Gnansounou, and colleagues. 2007a. Life Cycle Inventories of Bioenergy. ecoinvent report No.17. Dübendorf, CH: Swiss Centre for Life Cycle Inventories. www.ecoinvent.ch.

Jungbluth, N., R. Frischknecht, M.F. Emmenegger, and M. Tuchschmid. 2007b. RENEW: Renewable fuels for advanced powertrains - Life Cycle Assessment of BTL-fuel production: Inventory Analysis. ESU-Services Ltd. http://www.renewfuel.com/fs_documents.php. Accessed January 11, 2010.

Kalogo, Y., S. Habibi, H.L. MacLean, and S.V. Joshi. 2007. Environmental Implications of Municipal Solid Waste-Derived Ethanol. Environmental Science \& Technology 41(1): 35-41. Accessed April 22, 2009.

Kamm, B., P.R. Gruber, and M. Kamm. 2006. Biorefineries - Industrial Processes and Products: Status Quo and Future Directions - Volume 2. Vol. 2. 2 vols. Wiley-VCH, April 21.

Khoo, H.H. 2009. Life cycle impact assessment of various waste conversion technologies. Waste Management 29(6): 18921900. Accessed June 18, 2009.

Kirchain, R. and F.R. Field. 2000. Process-based cost modeling: understanding the economics of technical decisions. Materials Systems Laboratory, Massachusetts Institute of Technology. http://msl1.mit.edu/msl/pubs/docs/PBCM_MatlSciEngEncyc_wref.pdf. Accessed January 13, 2010.

Klerk, A. de. 2007. Environmentally friendly refining: Fischer-Tropsch versus crude oil. Green Chemistry 9(6): 560-565. Accessed May 18, 2010.

Klerk, A. de. 2008. Fischer-Tropsch refining. South Africa: University of Pretoria, August 6. http://upetd.up.ac.za/thesis/available/etd-07282008-130342/. Accessed July 27, 2010.

Klerk, A. de, L.P. Dancuart, and D. Leckel. 2005. Chemicals Refining from Fischer-Tropsch synthesis. 18th World Pet. Congr. Johannesburg, South Africa.

Koornneef, J., T. van Keulen, A. Faaij, and W. Turkenburg. 2008. Life cycle assessment of a pulverized coal power plant with post-combustion capture, transport and storage of CO2. International Journal of Greenhouse Gas Control 2(4): 448467. Accessed July 19, 2011.

Lettenmeier, M., H. Rohn, C. Liedtke, and F. Schmidt-Bleek. 2009. Resource productivity in 7 steps : how to develop ecoinnovative products and services and improve their material footprint. Wuppertal Spezial 41. Wuppertal, Germany: Wuppertal Institut für Klima, Umwelt, Energie GmbH. http://www.wupperinst.org/uploads/tx_wibeitrag/ws41.pdf. Accessed November 30, 2010.

Marano, J. and J. Ciferno. 2001. Life-Cycle Greenhouse-Gas Emissions Inventory for Fischer-Tropsch Fuels. U.S. Department of Energy National Energy Technology Laboratory. http://www.nrel.gov/docs/legosti/fy98/23076.pdf. Accessed May 21, 2009.

Menichetti, E. and M. Otto. 2009. Energy balance \& greenhouse gas emissions of biofuels from a life cycle perspective. In Biofuels: Environmental Consequences and Interactions with Changing Land Use, ed by. R.W. Howarth and Stefan Bringezu, 81-109. Proceedings of the Scientific Committee on Problems of the Environment (SCOPE) International Biofuels Project Rapid Assessment, 22-25 September 2008, Gummersbach Germany. Ithaca NY, USA: Cornell University.

Morschbacker, A. 2009. Bio-Ethanol Based Ethylene. Polymer Reviews 49(2): 79. Accessed June 17, 2009.

Münster, M. and H. Lund. 2009. Use of waste for heat, electricity and transport--Challenges when performing energy system analysis. Energy 34(5): 636-644. Accessed October 21, 2009.

Niessen, W., C. Marks, and R. Sommerlad. 1996. Niessen WR, Marks CH, Sommerlad RE (1996) Evaluation of gasification and novel thermal processes for the treatment of municipal solid waste., August. Golden, Colorado: National Renewable Energy Laboratory (NREL), August.

NREL (National Renewable Energy Laboratory). 2008. U.S. Life Cycle Inventory Database (U.S. LCI), v1.6.0. National Renewable Energy Laboratory (NREL). http://www.nrel.gov/lci/database/. Accessed January 26, 2010. 
Nuss, P., S. Bringezu, and K.H. Gardner. 2012. Waste-to-Materials: The Longterm Option. In Waste to Energy: Opportunities and Challenges for Developing and Transition Economies, ed by. Avraam Karagiannidis, 1-26. London: Springer London. http://www.springerlink.com/content/kt62v80040617k30/. Accessed January 15, 2012.

Nuss, P., K.H. Gardner, and J.R. Jambeck. 2013. Comparative Life Cycle Assessment (LCA) of Construction and Demolition (C\&D) Derived Biomass and U.S. Northeast Forest Residuals Gasification for Electricity Production. Environmental Science \& Technology 47(7): 3463-3471. Accessed July 19, 2013.

Paisley, M., K. Creamer, T. Tweksbury, and D. Taylor. 1989. Gasification of refuse derived fuel in the Battelle high throughput gasification system. U.S. Department of Energy, July 1. http://www.osti.gov/bridge/servlets/purl/5653025QRQFYH/. Accessed October 25, 2010.

Redman, A. 2005. Production of olefins and oxygenated compounds from Fischer-Tropsch. 18th World Pet. Congr. Johannesburg, South Africa.

RENEW (Renewable Fuels for Advanced Powertrains). 2006. RENEW - Renewable fuels for advanced powertrains Integrated Project Sustainable energy systems: WP 5.4 Technical Assessment Scientific Report. Europäisches Zentrum für erneuerbare Energie Güssing GmbH under suppor of Daimler Chryler AG, Volkswagen AG, Volvo Technologies Institute for Energy and Environment, Deutsche BP, Paul Scherer Institut, Total, Zentrum für Sonnenenergie- und Wasserstoffforschung. http://www.renew-fuel.com/fs_documents.php. Accessed November 5, 2010.

Ritthoff, M., H. Rohn, and C. Liedtke. 2002. Calculating MIPS - Resource Productivity of Products and Services. Wuppertal Spezial 27e. Wuppertal, Germany: Wuppertal Institut für Klima, Umwelt, Energie GmbH.

http://www.wupperinst.org/en/publications/entnd/index.html?beitrag_id=716\&bid=169. Accessed September 26, 2010.

Schmidt, J. 2003. Oekobilanzierung von verschiedenen Wegen der Rest- und Bioabfallentsorgung auf Basis des MIPSKonzeptes. Diplomarbeit, Wuppertal, Germany: Bremen University and Wuppertal Institute for Climate, Environment, and Energy.

Spath, P.L. and D.C. Dayton. 2003. Preliminary Screening - Technical and Economic Assessment of Synthesis Gas to Fuels and Chemicals With Emphasis on the Potential for Biomass-Derived Syngas. Technical Report. U.S. Department of Energy National Renewable Energy Technology Laboratory. http://www.nrel.gov/docs/fy04osti/34929.pdf.

Steynberg, A.P., W.U. Nel, and M.A. Desmet. 2004. Large scale production of high value hydrocarbons using Fischer-Tropsch technology. In Natural Gas Conversion VII, Proceedings of the 7th Natural Gas Conversion Symposium, Volume 147:37-42. Elsevier. http://www.sciencedirect.com/science/article/B8GYB-4NXH8XHD/2/fe82386cd4b7164e1b30552d2f9192bd. Accessed July 8, 2010.

Stichnothe, H. and A. Azapagic. 2009. Bioethanol from waste: Life cycle estimation of the greenhouse gas saving potential. Resources, Conservation and Recycling 53(11): 624-630. Accessed September 10, 2009.

UBA (Umweltbundesamt). 2010. ProBas - Lebenszyklusdatenbank [Life Cycle Inventory Database]. Dessau (Germany); Freiburg (Germany): Umweltbundesamt (German Federal Environmental Agency) and Öko-Institut. http://www.probas.umweltbundesamt.de/php/index.php. Accessed November 22, 2010.

UN-HABITAT. 2010. Solid Waste Management in the World's Cities: Water and Sanitation in the World's Cities 2010. Earthscan Publications Ltd., April.

USDOL (United States Department of Labor). 2011. Consumer Price Index. United States Department of Labor, February. $\mathrm{ftp}: / / \mathrm{ftp}$. bls.gov/pub/special.requests/cpi/cpiai.txt. Accessed February 21, 2011.

Valkenburg, C., M. Gerber, C. Walton, S. Jones, B. Thompson, and D. Stevens. 2008. Municipal Solid Waste (MSW) to Liquid Fuels Synthesis, Volume 1: Availability of Feedstock and Technology. Richland, WA (US): Pacific Northwest National Laboratory, December. http://www.pnl.gov/main/publications/external/technical_reports/PNNL-18144.pdf. Accessed October 30, 2009.

Vliet, O.P.R. van, A.P.C. Faaij, and W.C. Turkenburg. 2009. Fischer-Tropsch diesel production in a well-to-wheel perspective: A carbon, energy flow and cost analysis. Energy Conversion and Management 50(4): 855-876. Accessed June 22, 2009. 
Weiss, M., M. Patel, H. Heilmeier, and S. Bringezu. 2007. Applying distance-to-target weighing methodology to evaluate the environmental performance of bio-based energy, fuels, and materials. Resources, Conservation and Recycling 50(3): 260-281. Accessed December 10, 2009.

Zah, R., C. Binder, S. Bringezu, J. Reinhard, A. Schmid, and H. Schütz. 2010. Future Perspectives of 2nd Generation Biofuels. vdf Hochschulverlag AG, June 25.

About the Authors

Philip Nuss was a PhD student at the University of New Hampshire in Durham, NH, USA at the time the article was written.

He is currently a postdoctoral associate and lecturer at the Yale School of Forestry \& Environmental Studies in New Haven,

CT, USA. Kevin Gardner is a Professor of Civil Engineering at the University of New Hampshire, Durham, NH, USA.

Stefan Bringezu is director at the Wuppertal Institute and professor for sustainable resource management at the Center for Environmental Systems Research at the University of Kassel, Germany.

Supporting Information

Additional supporting information may be found in the online version of this article:

Supporting Information S1: This supporting information contains further details on LCA methodology, the assumptions used for the carbon recycling systems along with tables of the foreground life cycle inventories, and contribution analysis for each carbon recycling system and impact category. In addition, detailed figures for the sensitivity analysis are provided. 
${ }^{1}$ Traditional mechanical or chemical recycling would still be the preferred option if less resource and energy intensive than carbon recycling routes investigated in this paper.

${ }^{2}$ In this paper, MSW refers to the mixed waste stream from municipalities. Compostable waste refers to the biodegradable fraction of MSW that is recovered together with recyclables during MSW classification in a sorting plant. BMSW is used to describe the refuse-derived biodegradable waste fraction diverted to carbon recycling systems (see also subsequent footnote).

${ }^{3}$ While in reality the refuse-derived fraction (RDF) consists of paper, cardboard, woody biomass, food, and yard wastes, as well as plastics, to simplify the analysis with regards to biogenic vs. fossil carbon flows, we assume that all waste diverted to the carbon recycling systems is of bio-based origin only (here termed: BMSW).

${ }^{4}$ Material Input per Service Unit (MIPS)

${ }^{5}$ Characterization factors from (Bare and colleagues 2002) were developed for the United States and are hence used to calculate region-specific impacts including smog and acidification in the LCA model, in line with the geographical scope of this study.

${ }^{6}$ Carbon storage is included to be in line with the WARM model (EPA (U.S. Environmental Protection Agency) 2006) in which carbon stored in landfills is counted as an anthropogenic sink.

${ }^{7}$ Accounting for carbon sequestration in ethylene assumes that ethylene-based durable goods would (similar to landfills) store biogenic carbon over the course of several years. This assumption obviously depends on the life-time of products generated which is not further investigated.

${ }^{8}$ One kilogram $(\mathrm{kg}, \mathrm{SI}) \approx 2.204$ pounds $(\mathrm{lb})$.

${ }^{9}$ According to (EPA (U.S. Environmental Protection Agency) 2006), using non-baseload power might provide a more accurate estimate of the marginal emission rates (which would most likely be offset by electricity produced as co-product e.g. from novel carbon recycling schemes and waste energy systems) than the average U.S. power mix.

${ }^{10}$ For comparison, (Chiang 2005) use a discount rate of $15 \%$ and 25 years for biomass-to-ethylene systems, and (van Vliet and colleagues 2009) use a $10 \%$ discount rate and 10 years for biomass-based FTS systems. 
${ }^{11}$ Given a BMSW water content of 37\% (wt.), the energy requirement for drying is $1.57 \mathrm{MJ} / \mathrm{kg}$ syngas (Battelle), $1.36 \mathrm{MJ} / \mathrm{kg}$ syngas (MTCI), and 4.16 $\mathrm{MJ} / \mathrm{kg}$ FT-liquids (Choren). The heat for drying is supplied from waste heat generated during the gasification/FTS process (Battelle: $4.3 \mathrm{MJ} / \mathrm{kg}$ syngas, MTCI: 3.7 MJ/kg syngas, Choren: 4.9 MJ/kg FT-liquids) (see also supporting information section 2.2).

${ }^{12}$ Includes carbon storage in landfills and energy offsets (U.S. average power, $0.775 \mathrm{~kg} \mathrm{CO}_{2}$-eq $/ \mathrm{kWh}$ ). U.S. average landfills include systems with/without landfill gas (LFG) recovery equipment either for flaring or energy recovery. See supporting information Tables 10 and 11 for more details. Carbon dioxide equivalent $\left(\mathrm{CO}_{2}\right.$-eq) is a measure for describing the climate-forcing strength of a quantity of greenhouse gases using the functionally equivalent amount of carbon dioxide as the reference.

${ }^{13}$ One kilowatt-hour $(\mathrm{kWh}) \approx 3.6 \times 10^{6}$ joules $(\mathrm{J}, \mathrm{SI}) \approx 3.412 \times 10^{3}$ British Thermal Units (BTU).

${ }^{14}$ This includes a 5\% line loss rate for WTE facilities utilizing RDF according to (EPA (U.S. Environmental Protection Agency) 2006).

${ }^{15}$ One megajoule $(\mathrm{MJ})=10^{6}$ joules $(\mathrm{J}, \mathrm{SI}) \approx 239$ kilocalories $(\mathrm{kcal}) \approx 948$ British Thermal Units (BTU).

${ }^{16}$ The goal of including the BLUE Map mix in our analysis is not to exactly estimate its potential future impacts, but rather use it as a widely accepted proxy to investigate how an envisaged low-carbon energy mix, based on large shares of renewables, will impact results of our LCA model.

${ }^{17}$ Consisting of electricity from coal-fired power plants.

${ }^{18}$ Here calculated as: $\left(\operatorname{LHV}_{\text {FT-liquids }}+\mathrm{LHV}_{\text {Excess Electricity }}\right) /\left(\mathrm{LHV}_{\mathrm{BMSW} \text { input }}\right)$

${ }^{19}$ One metric ton $(\mathrm{t})=10^{3}$ kilograms $(\mathrm{kg}, \mathrm{SI}) \approx 1.102$ short tons.

${ }^{20}$ However, yields are based on FT-naphtha steam cracking test runs for the production of light olefins.

${ }^{21}$ Carbon conversion efficiency $=$ Chemical Feedstock $\left[\mathrm{Kg}_{\text {carbon out }}\right] /$ Feedstock $\left[\mathrm{kg}_{\text {carbon in }}\right] \mathrm{x} 100 \%$.

${ }^{22}$ Non-baseload power from coal-fired power plants. A marginal power mix is included to be in line with assumptions from the EPA WARM model, which assumes that electricity displaced is fossil-derived (see also section 2.7 in the supporting information).

${ }^{23}$ This does not take into account possible future changes in efficiencies for both conventional WM systems as well as carbon recycling routes. 